\title{
BEVERIDGE CURVES OF THREE HUNGARIAN COUNTIES WITH THE HIGHEST PUBLIC EMPLOYMENT RATES
}

\author{
Tímea GYÖRI ${ }^{\mathrm{a}}$, Bálint JUHÁSZ ${ }^{\mathrm{b}}$ \\ a Szent István University - Faculty of Economincs and Social Sciences, H-2100 Gödöllö, Páter Károly \\ street1.gyoritimi05@gmail.com \\ ${ }^{\mathrm{b}}$ Szent István University - Faculty of Economincs and Social Sciences, H-2100 Gödöllö, Páter Károly \\ street 1. ifj.juhasz.balint@gmail.com
}

Cite this article: Györi, T., Juhász, B. (2020). Beveridge curves of three Hungarian counties with the highest public employment rates. Deturope. 12(2), 122-139.

\begin{abstract}
In the study, we use the Beveridge curve to examine the labor market processes in Hungary, and in three selected counties, in recent years. The counties were selected on the basis of the highest public employment rates in 2019. The subjects of our further labor market analyzes were Borsod-Abaúj-Zemplén, Szabolcs-Szatmár-Bereg and Békés counties. For the counties, the curves were made using two methods for the period 2013-2019, first the unemployment rate for the working age population (15-64 years) and then the public employment indicator were compared with the job vacancy rate. In the course of the research, we examined the relationship between the unemployment rate and the public employment indicator in the selected counties. To examine the correlation, Pearson's correlation analysis was performed. With the correlation calculation, we were able to get an answer to the strength of the relationship between the variables (in our case, the two labor market indicators). In connection with the coefficient, we examined the percentage by which one criterion explains the variance of the other criterion using a coefficient of determination.
\end{abstract}

Keywords: Beveridge curve, job vacancy rate, public employment rate, Pearson's coefficient

\section{INTRODUCTION}

The National Employment Service (NES) has been continuously registering the unemployed since 1989, the most basic area of the Office's data collection activity is unemployment (Fejes, et al., 2006).

According to NES data, the average monthly number of registered jobseekers in 2013 was 527,624 , which decreased by approximately $50 \%$ by 2019 , when 252,550 persons were registered. The number of people with a primary education was 108,288. The educational attainment of registered jobseekers in 2019 was as follows: $43.2 \%$ had 8 primary or lower education degrees, $25.2 \%$ had vocational or vocational education, $25.4 \%$ had secondary education and only $6.2 \%$ had tertiary education. Jobseekers with primary education were mainly concentrated in two counties, $16.63 \%$ of them lived in Borsod-Abaúj-Zemplén county and $14.22 \%$ of them in Szabolcs-Szatmár-Bereg county. Unemployment data by educational 
attainment suggest that educational attainment significantly determines the chances of becoming unemployed. Those with higher (primarily tertiary) education typically enjoy greater protection against becoming unemployed (Hajdú-Koncz, 2020).

In addition to unemployment statistics, the NES data series also provide information on labor demand developments. Job vacancy statistics are based on labor demand notifications from employers. The largest proportion of companies are looking for an employee for an unskilled job, because they are basically interested in applying for jobs that can be filled in a subsidized form. Most job vacancies were registered in 2019 in Borsod-Abaúj-Zemplén county, excluding Budapest.

The financial and economic crisis of 2008 also spilled over into the labor market, interrupting the European Union's employment growth trend and increasing the number of unemployed in the 27 member states by a total of 5 million in 2009 (European Commission, 2013). The peculiarity of the situation in Hungary is that in a relatively short period of time the Hungarian labor market experienced the second shock after the turn of the 1990s. The already low employment rate, which had hardly improved since the post-transition crisis, fell to $55.5 \%$ in the population aged 15-64, according to the Central Statistical Office (CSO) in 2009. Roughly 130,000 jobs were lost, and the unemployment rate reached $10.5 \%$.

The new labor market situation created as a result of the crisis and the concomitant lack of income forced state intervention (Csoba, 2010). Tackling the crisis in the labor market required a strong increase in public involvement, which was reflected in employment policy. Within the system of tools for dealing with labor market anomalies, the expansion of the possibility of public employment in Hungary has been given priority. In general, a person who may be employed and has reached the age of 16 , as well as a jobseeker registered with the district office or a person receiving rehabilitation benefits under the Disability Benefits Act, may be included in public employment.

\section{THEORETICAL BACKGROUND}

Today, public employment programs can be found in the active employment policy instruments of more than 40 countries (Ruby - Sampson, 2019). In the United States (Job Corps, National Supported Work) and the United Kingdom (New Deal for Young People), active employment policy programs address a specific problem or age group. Comprehensive national programs are organized in most continental European countries, where regions with low employment rates typically have higher levels of public employment (Kessing - Strozzi, 2017). According to international research on the topic, targeted, complex treatment programs work more 
efficiently than extensive programs (Hudomiet - Kézdi, 2008). As a result of the 2008 crisis, Latvia, Hungary, Slovenia, Portugal, and the Czech Republic, among the EU member states, used their public employment programs on a larger scale (Kálmán, 2015). Overall, welltargeted public works programs can be a means of combating poverty by providing temporary employment (Brown-Koettle, 2012; Zimermann, 2014).

In Hungary, the active employment policy instruments and the assistance system underwent major changes in 2011. The National Public Employment Program has been introduced, which can be considered as a "workfare" type public employment system. The term "workfare" evolved from the combination of the words working-for-benefit, which means "work for support" (Lodemel, 2000). It is characteristic of "workfare" systems that the beneficiaries have to meet various conditions aimed at improving the beneficiary's employability (training, rehabilitation, gaining work experience), on the other hand, they also require activities that are beneficial to society (for example public works).

The year 2012 was another milestone, the Start work programs were launched, in which the economic goal structure of value creation also appeared. Between 2009 and 2016, the number of participants in public employment increased steadily; in 2016 the average monthly headcount reached 223,469 persons. With the narrowing of the labor reserve starting from 2017, the number of public employees also decreased; by 2019 it decreased to 106,259 people.

There are large differences between the member states of the European Union in the proportion of GDP allocated to labor market interventions. According to the European Commission's Labor Market Policy (LMP), Hungary was in the middle in terms of total active employment policy expenditure in 2018: as a share of GDP, Hungary spent less on active assets $(0.588 \%)$ than Germany (1.388\%) and the Nordic countries, but more than some Central and Eastern European and Mediterranean countries. On the 10th anniversary of the crisis, Hungary $(0.411 \%)$ spent the most on direct job creation as a share of GDP, alongside Finland $(0.196 \%)$, Ireland $(0.151 \%)$, Croatia $(0.120 \%)$, and Spain $(0.118 \%)$. According to LMP data, most of the employment policy expenditures in Hungary until 2011 were spent on jobseeker's allowance and social assistance, the distribution of expenditures by measures changed from 2012: the most significant expenditures already served direct job creation (public employment programs).

Compared to urban areas, the employment situation in rural areas is much worse (Bódi Obádovics 2000). In Hungary, the flagship of public employment is the eastern part of the country. Borsod-Abaúj-Zemplén, Szabolcs-Szatmár-Bereg, Hajdú-Bihar, and Békés counties are affected by significant employment policy interventions. Fig. 1 can serve as an eclectic example of the East-West divide axis typical of Hungary. In contrast to the settlements of Western Transdanubia, Central Hungary and Central Transdanubia, which present much more favorable economic indicators, public employment is of paramount importance in the 
settlements of our worst situation regions (in the economically less developed Northern Great Plain; and in Northern Hungary, which has been severely affected by the decline of heavy industry).

Figure 1 Number of public employees in 2019 (persons)

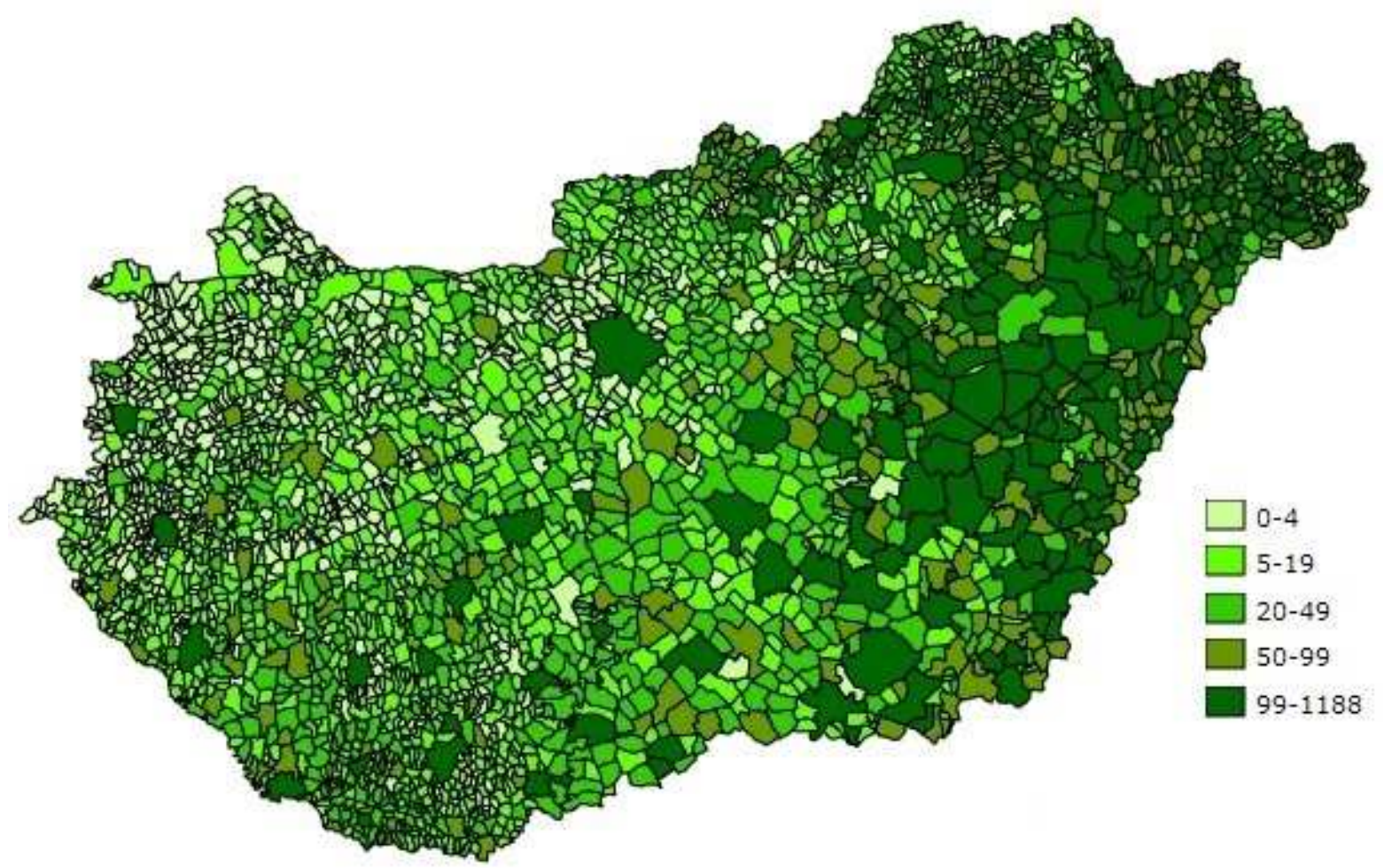

Source: Own editing based on National Spatial Development and Spatial Planning Information System data (2019)

\section{Research aims and hypotheses}

In the first part of the research, we sought the answer to how labor demand and supply developed in Hungary between 2013 and 2019, assuming that the fit of the search-pairing variables became closer. Subsequently, we examined the development of the 2019 county-level public employment indicators in order to narrow the research area, making it probable that the value of the indicator is outstanding in the more economically backward counties.

In a further phase of the research, we also examined changes in labor market demand and supply for the counties with the three highest public employment rates selected, comparing them with data at the national level. We hypothesized that the models of counties with higher public employment rates would differ significantly from the national average. To facilitate the interpretation of the obtained results, we also examined the educational attainment of jobseekers in the counties, assuming that the proportion of the unemployed with low educational attainment is significantly high in counties with a high public employment rate. The analysis included a correlation study between the unemployment rate and the public employment rate, 
supposing a positive linear relationship between the two criteria. During the performed correlation study, statistical hypothesis pairs (null and alternative hypotheses) were set up. The null hypothesis assumes equality, flawlessness, so in our case the unemployment rate and the public employment rate are equal. Our alternative hypothesis to the null hypothesis assumes the difference between the two variables.

In line with the research objectives, we formulated the following hypotheses, which were supplemented with the pairs of hypotheses needed to examine the significance of the correlation coefficients:

H1. From 2017, the matching of the search-pairing variables of the labor market in Hungary (in our case: the unemployment rate and the ratio of vacancies) is more optimal.

H2. In the selected counties, there is a positive linear relationship between the unemployment rate and the public employment rate. Null hypothesis: The unemployment rate and the public employment rate are equal. Alternative hypothesis: The unemployment rate and the public employment rate are not equal.

H3. Models for selected counties with higher public employment rates differ significantly from the national average.

H4. The proportion of the unemployed with a low level of education is significantly high in counties with a high public employment rate.

H5. There is a positive linear relationship between the ratio of job vacancies to the number of unemployed and the share of the unemployed with primary education. Null hypothesis: The values taken by the two variables are equal. Alternative hypothesis: The values taken by the two variables examined are not equal.

\section{DATA AND METHODS}

During the preparation of the study, the emphasis was basically on the analysis of statistical data collected from secondary sources. The information on unemployment required for the surveys was provided by the public databases of the NES, while the data used in the analyzes related to public employment were provided by the public employment database compiled by the Ministry of the Interior. The interval of the study is 7 years, in determining the period we took into account the development of the headcount data of public employment. In Hungary, most people participated in various public employment programs in 2016 (223,469 people), therefore we selected 2016 as the median of the research interval. In order to examine the ongoing processes, we also examined the 3 years before and after the selected year.

The labor market can be analyzed with many models, the best known of which are the searchmatching models (Morvay, 2012). In the framework of the research, the Beveridge curve was 
selected from the search-matching models suitable for the analysis of the labor market. The model basically starts from the pairing of job seekers and job advertisers. The curve can be well applied to the examination of rural areas in Hungary, because in the examination of these areas the distorting effect of wages is less pronounced in the model, as typically the wage determination means the mandatory minimum wage. In our research, the curve illustrates the relationship between the unemployment and job vacancy rates for the working-age population (15-64 years). The job vacancy rate is the quotient of the number of vacancies and the number of employees (Lipták, 2014). The authors Dow and Dicks-Mireaux, who created the curve, found a negative relationship between the two rates, and if the economy is in recession, high unemployment is associated with few job vacancies (Rodenburg, 2007). As a first step in the study, we analyzed the national labor market data between 2013 and 2019 using the selected search-pairing model.

In the next phase of the research, the counties that were the subject of our further labor market analyzes were identified. When selecting the counties, we took into account the development of the public employment indicator in 2019, and further analyzes were carried out in the counties with the three highest values. The indicator chosen to delimit the research area shows the weight of public employment as an active labor market tool. The public employment indicator - as defined by the Ministry of the Interior - is the ratio of the average monthly number of participants in public employment to the working-age population.

In the selected counties in the period between 2013 and 2019, the relationship between the unemployment rate and the public employment indicator and its strength was explored by correlation analysis. To examine the correlation, Pearson's correlation analysis was performed. Correlation calculation provides an answer to the question of the strength of the relationship between the variables (in our case, the two labor market indicators). It should be noted that the correlation analysis was performed with a low number of items, so it is only possible to explore the direction of the relationships in the first place. Pearson's correlation is a linear statistic, so it gives a reliable value for data sets where the relationship between the two variables can be described by a line (Wilcox, 1998). The value of the coefficient varies between +1 and -1 , the closer the relationship is, the closer the absolute value of the coefficient is to 1 . The coefficient is strong in absolute terms in the range of 0.7-1; medium at 0.3-0.7 intervals; and indicates a weak correlation at 0-0.3 intervals (Nemes Nagy, 2005). If the sign of the correlation coefficient is positive, then there is a straight, otherwise inverse proportionality between the two variables. If there is no correlation $(\mathrm{r}=0)$ the two variables are not necessarily independent, but there is certainly no linear type of relationship between them. However, Pearson's coefficient is not suitable for exploring causal relationships, so we can only say whether the two variables examined are related, but we do not get an answer as to what caused this. 
The result of the correlation test is strongly influenced by the outlier points (Vargha, 2000). Outliers are meaningless data for the model, which can significantly affect the parameters of the regression line fitted to the model (Hawkins, 1980). In the framework of the research, we considered outlier points as values that significantly distorted the obtained models. A method based on logarithmization was chosen to filter out outlier points. The pre-recorded constant product of the mean of the logarithms $(\log 2)$ calculated for adjacent sample elements (in our case, the value of the constant is 6) is less than the difference between the two largest elements, then the largest element was considered an outlier. The constant can vary depending on the accuracy with which we want to determine the outliers (Verma, 1997).

Correlation results were also hypothesized to support whether the results obtained were significant. Significance (p) is the probability of committing the first type of error. In statistics, a result is significant if the probability that it was obtained as a mere play of chance remains below a predetermined value (Vita, 2011). Depending on the results obtained in the study, the chosen values are $1 \%$ and $5 \%(p=0.01$ and $p=0.05)$.

In the framework of the research, we examined with what coefficient of determination the percentage by which one criterion explains the variance of the other criterion (the mean of the square of the deviation from the mean). Assuming a linear functional relationship between the variables, the coefficient of determination is equal to the square of the Pearson correlation coefficient (Zhang, 2017). The value of the indicator is between 0 and $100 \%$, so it determines the strength of the relationship in $\%$.

The Beveridge curves for the counties depicted data for the period 2013-2019. The curves were made using two methods, first, the unemployment rate for the working-age population (15-64 years) and then the public employment indicator were compared with the job vacancy rate. To facilitate the interpretation of the obtained results, we also examined the educational attainment of jobseekers in the counties.

\section{RESULTS}

\section{National level research}

In the first part of the study, the data were evaluated at the national level. On the Beveridge curve, we illustrated the relationship between the vacancy rate of the 15-64 age group (the ratio of vacancies to the economically active population) and its relative unemployment rate in the interval between 2013 and 2019. Fig. 2 clearly shows that in the growth phase between 2013 and 2016, the job vacancy rate increased with the decrease in the unemployment rate, so the two factors moved in opposite directions. 
Increased employment migration, mainly to EU member states, also contributed to the improving employment data, which can also be seen in the Beveridge curve. Emigration was a response to employment opportunities that had become more precarious as a result of the crisis and to an increase in the financial burden on householders (increase in foreign currency loans). This picture is further nuanced by demographic processes, with natural reproduction lagging far behind the mortality rate of the regional and local population, besides the fact that human resource reserve remaining locally is characterized by an aging age structure. Foreign employment, emigration, an aging population were all reduced domestic indicators.

Figure 2 Beveridge curve - national average (2013-2019)

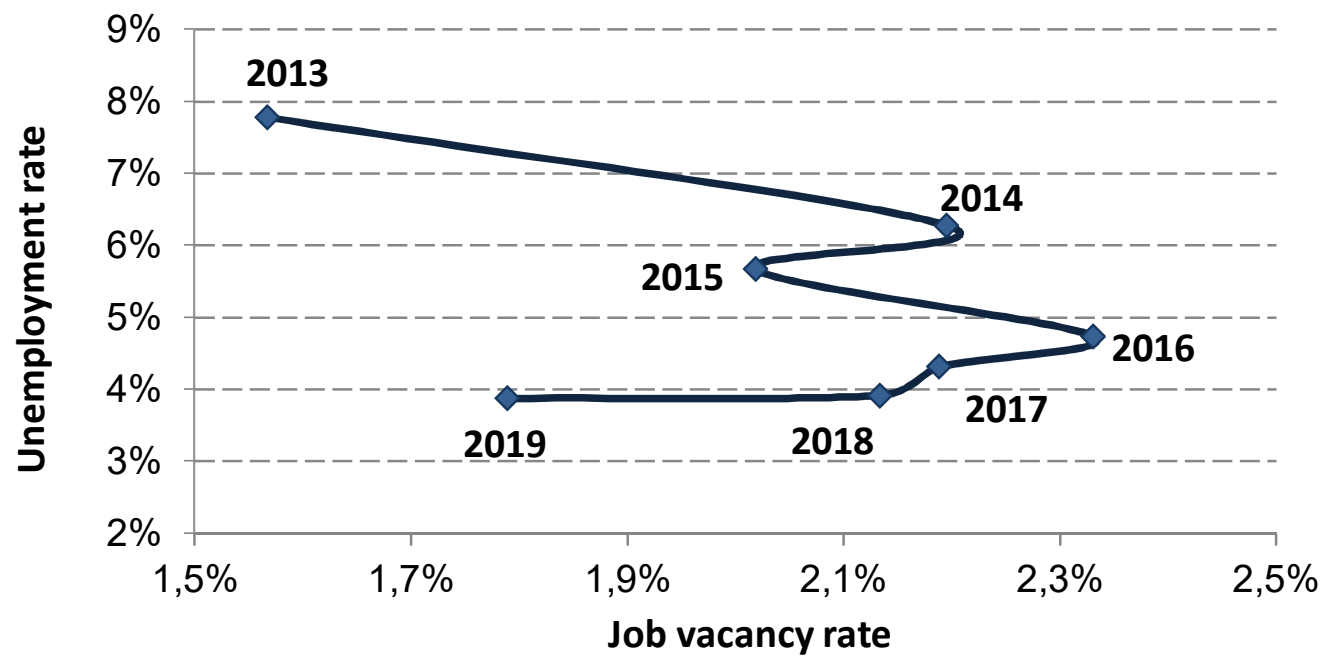

Source: Own construction based on CSO and NES data

After 2016, while unemployment continued to decline, the job vacancy rate also showed a declining trend. An inward shift in the overall curve, a decrease in the job vacancy rate, in addition to a decrease in the unemployment rate, may even indicate an improvement in the matching. When the variables fit more optimally, it is easier to fill vacancies than before, because then the skills required by employers (qualifications, experience) and the skills of the workforce show leveling. However, based on the research results, the degree of fit cannot be considered more optimal; only in the current labor market situation, companies were forced to lower their expectations of employees.

\section{Demarcation of the narrower research area}

In the next phase of the research, the counties with the three highest indicators were selected on the basis of the values of the 2019 public employment indicators. Fig. 3 illustrates the data on the number of public employees and the public employment indicator for 2019 by county. 
The data on the number of public employees can provide information on the extent of employment policy interventions. The number of public employees in 2019 was outstanding in Szabolcs-Szatmár-Bereg (20,860 people), Borsod-Abaúj-Zemplén (20,163 people), and HajdúBihar counties (10,208 people).

Figure 3 Public employment rates in 2019

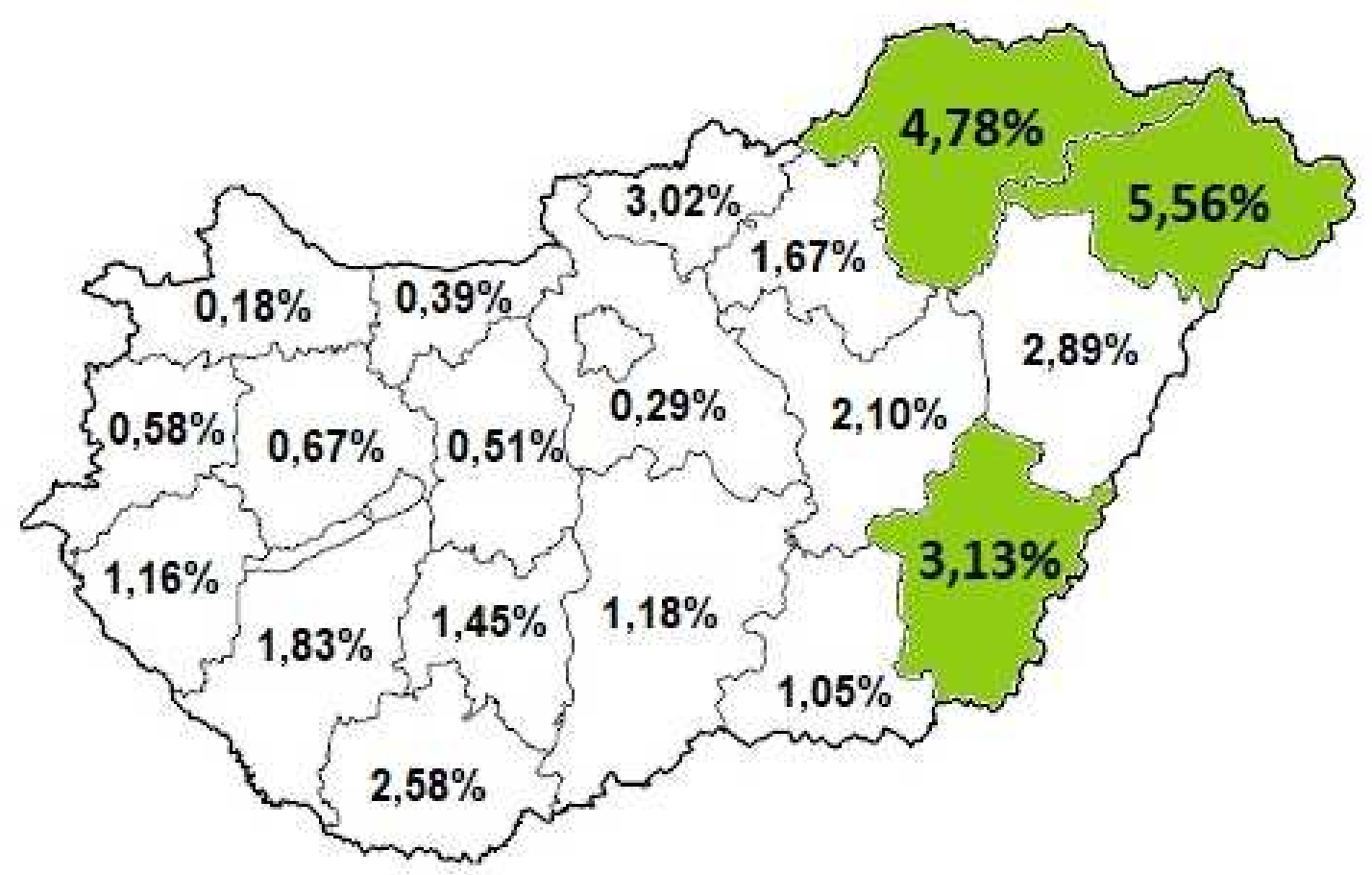

Source: Own construction based on Ministry of the Interior data (2019)

However, the basis for the selection of counties was not the number of public employees, but the public employment indicator, because with the help of the indicator we can get a more accurate picture of the importance of public employment. The value of the indicator was the highest in Szabolcs-Szatmár-Bereg (5.56\%), Borsod-Abaúj-Zemplén (4.78\%), and Békés (3.13\%) counties in 2019 (Fig. 3). Therefore, the subject of our further analyzes was these three counties. The selected counties belong to the less developed, low-income convergence club of Hungary (Egri-Kőszegi 2018, Egri 2019).

\section{Correlation test}

In the course of the research, we examined the relationship between the unemployment rate and the public employment rate in the selected counties. In the period 2013-2019, the relationships between the two indicators were explored using Pearson's correlation analysis. Tab. 1 shows the Pearson coefficient and significance values as well as the coefficient of determination. 
Table 1 Examining the relationship between unemployment and public employment

\begin{tabular}{l|ccc}
\hline \multicolumn{1}{c|}{ County } & $\begin{array}{c}\text { Pearson's } \\
\text { coefficient }(\mathrm{r})\end{array}$ & $\begin{array}{c}\text { Significance } \\
(\mathrm{p})\end{array}$ & $\begin{array}{c}\text { Determination } \\
\text { coefficient \% }\left(\mathrm{r}^{2}\right)\end{array}$ \\
\hline Szabolcs-Szatmár-Bereg & $-0,510$ & 0,242 & 26,01 \\
Borsod-Abaúj-Zemplén & $-0,286$ & 0,534 & 8,18 \\
Békés & $-0,222$ & 0,632 & 4,93 \\
\hline
\end{tabular}

Source: Own construction and calculation based on Ministry of the Interior data (2019)

The Pearson correlation analysis indicates a medium correlation between the unemployment rate and the public employment indicator in Szabolcs-Szatmár-Bereg county for the values between 2013 and 2019 ( $\mathrm{r}=-0.510)$. The connection is weak in the case of Borsod-AbaújZemplén and Békés counties. The value of the coefficient has a negative sign for all three counties. In the case of a negative coefficient, there is an inverse proportionality between the two variables examined, so the high unemployment rate is coupled with a low public employment rate. Outliers strongly influenced the results obtained, as evidenced by the low coefficients of determination. Low values (below 10\%) indicate, on the one hand, that the fit is weak, that the reality content of the model is low, and, on the other hand, that the explanatory power of the model is low.

After filtering out the outlier points, we can get a more accurate, realistic picture of the labor market. After filtering out the outliers, the coefficient indicates a positive, medium correlation $(r=0.3-0.7)$ for all three counties (Tab. 2). A positive sign indicates the generality that if the unemployment rate is high, the value of the public employment indicator will also be high.

The results cannot be considered significant because the probability that we obtained it only as a game of chance did not remain below the predetermined value for any of the counties.

Table 2 Coefficient value after filtering outlier points

\begin{tabular}{l|ccc}
\hline \multicolumn{1}{c|}{ County } & $\begin{array}{c}\text { Pearson's } \\
\text { coefficient }(\mathrm{r})\end{array}$ & $\begin{array}{c}\text { Significance } \\
(\mathrm{p})\end{array}$ & $\begin{array}{c}\text { Determination } \\
\text { coefficient } \%\left(\mathrm{r}^{2}\right)\end{array}$ \\
\hline Szabolcs-Szatmár-Bereg & 0,580 & 0,306 & 33,64 \\
Borsod-Abaúj-Zemplén & 0,684 & 0,203 & 46,79 \\
Békés & 0,636 & 0,248 & 40,45 \\
\hline \multicolumn{4}{l}{}
\end{tabular}

Source: Own construction and calculation based on Ministry of the Interior data (2019)

In our case, the coefficient of determination gives the answer to what percentage of the unemployment rate explains the variance of the public employment indicator. In the case of all examined counties, the result was over 30\%, the highest value was shown by Borsod-AbaújZemplén county. The coefficient expresses the explained variance, so the variance of the public employment indicator is explained for an unemployment rate in $46.79 \%$. 


\section{Analysis of selected counties}

For the selected counties, examining the period 2013-2019, the Beveridge curves were constructed using two methods. In the first step, we compared the county unemployment rate calculated for the working-age population (15-64 years) and job vacancy rate; then in the next step, we compared the job vacancy rate of the counties with the public employment indicator also.

Comparing the number of job vacancies to the number of unemployed, we can find out what percentage of jobseekers could be absorbed by labor demand if the demand and supply side were fully matched (the qualifications and experience required by employers and the skills of employees are the same).

In the equilibrium state, employers would have been able to employ $40 \%$ of the unemployed in Borsod-Abaúj-Zemplén county, 36\% in Békés county and 25\% in Szabolcs-Szatmár-Bereg county in 2019.

The unemployment rate decreased significantly in all three counties between 2013 and 2018, after that with some increase observed in 2019. In the period under review, the unemployment data improved by almost 4\% in Békés (Fig. 4) and Borsod-Abaúj-Zemplén (Fig. 6) counties and by approximately 7\% in Szabolcs-Szatmár-Bereg (Fig. 5) county.

The job vacancy rate no longer gives such a uniform picture, while in Szabolcs-Szatmár-Bereg and Békés counties the job vacancy rate decreased to approximately $2 \%$ by the end of the term, until then in Borsod-Abaúj-Zemplén county it increased to $3.41 \%$.

In Békés county, a trend similar to the national one took place in the period 2013-2019, unemployment decreased until 2016 and the job vacancy rate increased slightly, then the curve turned inwards thus, with fewer job vacancies, slightly more people sought work.

Examining Szabolcs-Szatmár-Bereg county, the curve also shifted inwards, where the shift is significant after 2014, with almost no change in the proportion of vacancies since 2015, while unemployment fell by $2.53 \%$ points.

According to the research, the previous statement that the improving trend is not due to a better match between supply and demand is also true for Békés and Szabolcs-Szatmár-Bereg counties. 
Figure 4 Beveridge curves - Békés county (2013-2019)



Source: Own construction based on Ministry of the Interior and NES data (2013-2019)

Figure 5 Beveridge curves - Szabolcs-Szatmár-Bereg county (2013-2019)
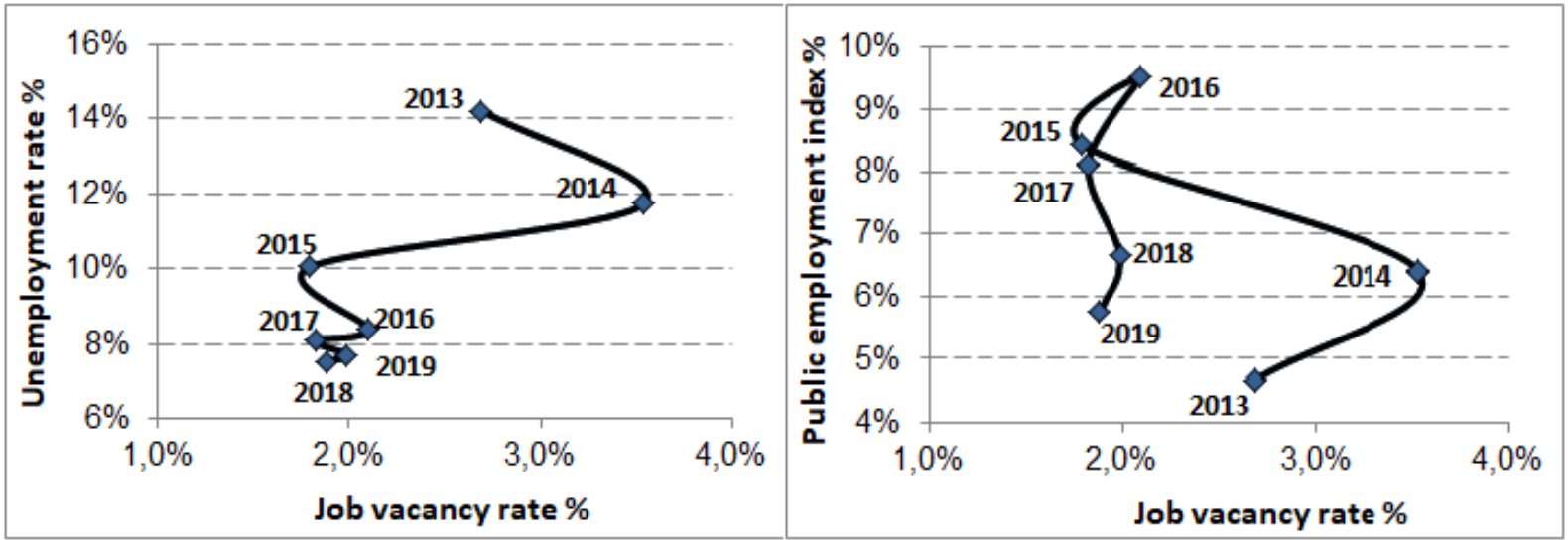

Source: Own construction based on Ministry of the Interior and NES data (2013-2019)

Figure 6 Beveridge curves - Borsod-Abaúj-Zemplén county (2013-2019)



Source: Own construction based on Ministry of the Interior and NES data (2013-2019)

The public employment indicator followed a similar trend in the counties examined, reaching its peak in 2016 and then approaching the baseline values again in 2019. The value of the indicator was the highest in Szabolcs-Szatmár-Bereg county (9.54\% in 2016). Examining the 
whole period, the change in the public employment rate in the counties ranged from 0.12 to $1.10 \%$ points in absolute terms.

The movement of the curves (Fig. 4, Fig. 5, Fig. 6) is in the opposite direction until 2016, while the unemployment rate decreases, the value of the public employment rate increases. The juxtaposition of the models is a good illustration of the inverse relationship between the improvement in the unemployment rate and the increase in the public employment rate.

Once the public employment peak is reached, the curves will reverse, and in addition to further declining unemployment, public employment also declined.

In Borsod-Abaúj-Zemplén county, a completely different picture emerged, the decreasing unemployment rate from year to year was accompanied by an increasing job vacancy rate. The special situation was contributed by the fact that the demand for labor was the highest here in the years under review (12.45\% of all vacancies reported in 2019) and the highest number of unemployed with general or lower education was registered here $(18,004$ persons, $16.63 \%$ of job seekers). The outstanding demand for labor on the national average mainly meant lowskilled jobs for which support could be requested.

Cartogram No. 7 represents the proportion of people with primary education in relation to the total unemployed at the settlement level. In Borsod-Abaúj-Zemplén (16.63\%) and SzabolcsSzatmár-Bereg (14.22\%) counties, the proportion of the unemployed with a low level of education represents a significant proportion

Figure 7 Proportion of unemployed with primary education by settlement, \% (2019.11)

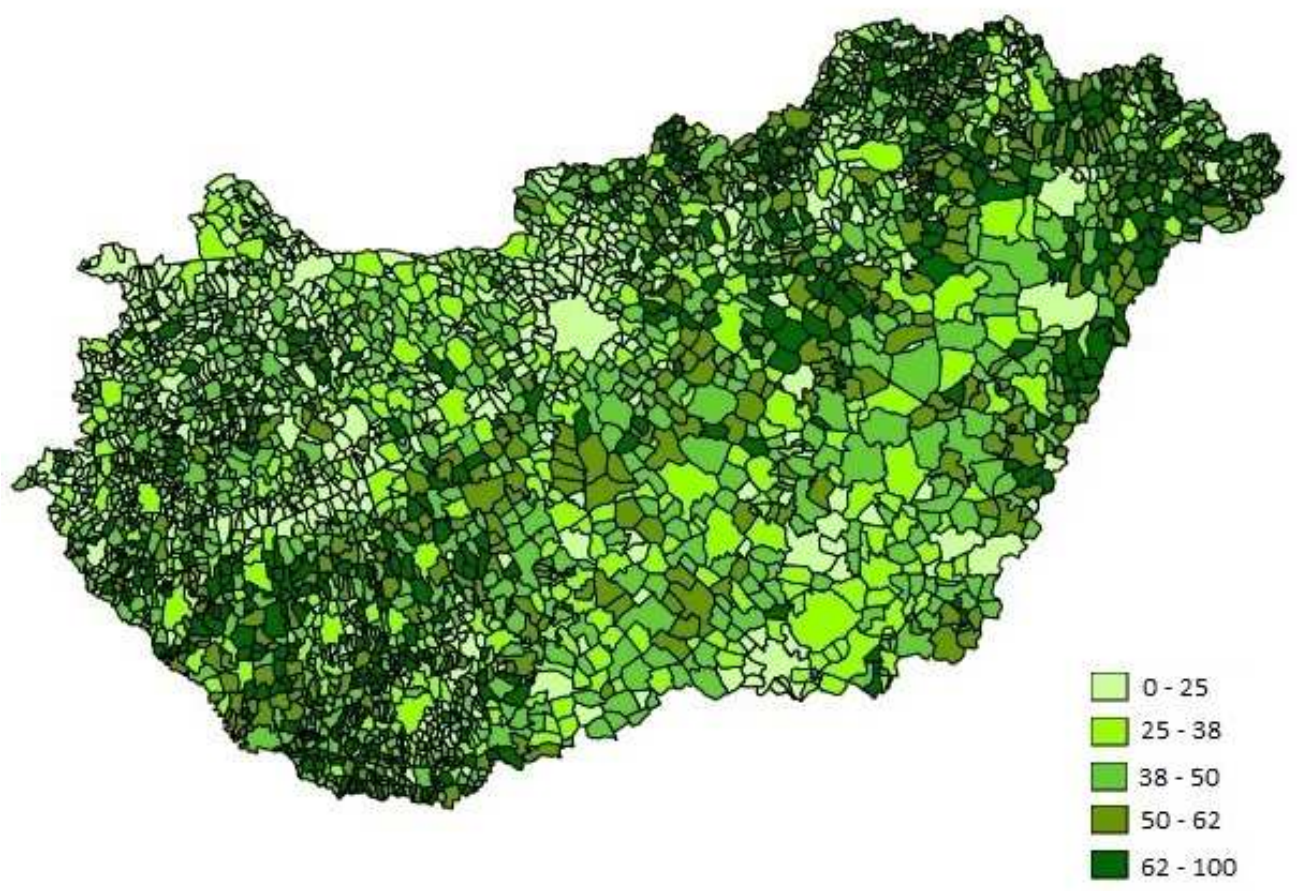

Source: Own editing based on National Spatial Development and Spatial Planning Information System (2019) 
In the case of Borsod-Abaúj-Zemplén county, the high job vacancy rate may be related to the proportion of registered job seekers with outstanding primary education.

The results of the study confirmed that the level of education obtained significantly determines the chances of becoming unemployed. Those with higher education typically enjoy greater protection against becoming unemployed.

We also examined the relationship between the ratio of job vacancies to the number of unemployed and the ratio of the unemployed with primary education. The results of the correlation test are shown in Tab. 3.

Table 3 Examining the relationship between the share of the unemployed with primary education and the job vacancy rate

\begin{tabular}{l|ccc}
\hline \multicolumn{1}{c|}{ County } & $\begin{array}{c}\text { Pearson's } \\
\text { coefficient }(\mathrm{r})\end{array}$ & $\begin{array}{c}\text { Significance } \\
(\mathrm{p})\end{array}$ & $\begin{array}{c}\text { Determination } \\
\text { coefficient \% }\left(\mathrm{r}^{2}\right)\end{array}$ \\
\hline Szabolcs-Szatmár-Bereg & $0,990^{* *}$ & 0,000 & 98,01 \\
Borsod-Abaúj-Zemplén & $0,965^{* *}$ & 0,000 & 93,12 \\
Békés & $0,911^{* *}$ & 0,002 & 82,99 \\
\hline
\end{tabular}

* Significant at $\mathrm{p}<0.05$ level, $* *$ Significant at $\mathrm{p}<0.01$ level Source: Own construction and calculation based on NES data (2019)

The Pearson's coefficient shows a strong $(\mathrm{r}<0.7)$ correlation between the two variables for all three counties. The coefficient is positive, so it is a directly proportional relationship, the higher the proportion of people with primary education, the higher the labor demand in relation to the number of unemployed. In Szabolcs-Szatmár-Bereg and Borsod-Abaúj-Zemplén counties we can state that the null hypothesis is true at $100 \%$, in the case of Békés county at $99.8 \%$. This means that the chances of obtaining a random value are minimal ( $0 \%$ and $0.2 \%)$.

The coefficients of determination were also evaluated as part of the study. The coefficient expresses the explained variance. The share of the unemployed with a primary education in Békés county in $82,99 \%$, in Borsod-Abaúj-Zemplén county in 93,12\%, Szabolcs-SzatmárBereg county in $98.01 \%$ explains the dispersion of the job vacancy rate.

\section{CONCLUSION}

In Hungary, the flagship of public employment is the eastern part of the country. In contrast to the settlements of Western Transdanubia, Central Hungary, and Central Transdanubia, which present much more favorable economic indicators, public employment is of paramount importance in the settlements of our previously worst-off regions, Northern Hungary and the economically less developed Northern Great Plain. 
Hypothesis $\mathbf{H 1}$ formulated at the beginning of the research, according to which the fit of the search-pairing variables of the labor market became more optimal, was rejected. Given the current labor market conditions, with the narrowing of the labor reserve starting in 2017, domestic companies are now looking for more employees than they are laying off. As an inseparable benefit of labor shortages, employers have been forced to lower their expectations of employees. This finding was also supported by Beveridge curves illustrating the relationships between the unemployment rate and the vacancy rate.

According to our hypothesis $\mathbf{H 2}$, there is a positive linear relationship between the unemployment rate and the public employment indicator in the selected counties. The performed Pearson correlation analysis, after filtering out the outlier points, confirmed a positive mean relationship between the two indicators. A positive sign indicates the generality that if the unemployment rate is high, the value of the public employment indicator will also be high. The juxtaposition of the Beveridge curves using the two methods is a good illustration of the proportionality between the improvement in the unemployment rate and the increase in the public employment rate up to 2016. Thus, hypothesis H2 was confirmed by the research.

Hypothesis $\mathbf{H 3}$ is considered valid for two examined counties. Based on the research results, it can be stated that it is also true for Békés and Szabolcs-Szatmár-Bereg counties that the improving trend is not due to a better match between supply and demand. In Borsod-AbaújZemplén county, the share of job vacancy rate increased next to the decreasing unemployment year by year. In order to facilitate the interpretation of the obtained results, we also examined the educational attainment of the jobseekers.

Hypothesis H4, according to which the proportion of the unemployed with a low level of education is significantly high in counties with a high public employment rate, was also confirmed. It was found that the highest proportion of unemployed people with a primary education is present in Borsod-Abaúj-Zemplén county in Hungary and - unlike the national average - the number of vacancies in this county also increased in the period under review.

The results of the research proved that the acquired educational qualification significantly determines the chances of becoming unemployed. Those with higher education typically enjoy greater protection against becoming unemployed.

The research also revealed a relationship between the ratio of job vacancies to the number of unemployed as well as the ratio of the unemployed with a primary education. The study confirmed hypothesis H5, the Pearson coefficient shows a strong $(r<0.7)$ correlation between the two variables for all three counties. The coefficient is a positive, so it is directly proportional 
relationship, thus higher the proportion of people with a primary education, the higher the labor demand in relation to the number of unemployed.

In the examined counties, if we take into account the public employees as unemployed, it can be stated that approximately $40 \%$ of the registered unemployed are still employed in the public employment system.

\section{SUMMARY}

In the study, we use the Beveridge curve to examine the labor market processes in Hungary, and in three selected counties, in recent years. The counties were selected on the basis of the highest public employment indicators in 2019. The subjects of our further labor market analyzes were Borsod-Abaúj-Zemplén, Szabolcs-Szatmár-Bereg, and Békés counties. For the counties, the curves were calculated using two methods for the period 2013-2019, first, the unemployment rate for the working-age population (15-64), and then the public employment rate was compared with the job vacancy rate. We assumed that the curves of the worst-performing counties differ significantly from the national average. In order to facilitate the interpretation of the obtained results, they also examined the educational attainment of jobseekers in counties.

During the preparation of the study, the emphasis was basically on the analysis of statistical data collected from secondary sources. The information on unemployment required for the research was provided by the public databases of the NES, while the data used in the analyzes related to public employment were provided by the public employment database compiled by the Ministry of the Interior.

In the course of our research, we examined the relationship between the unemployment rate and the public employment rate in the selected counties. To examine the correlation, Pearson's correlation analysis was performed. In connection with the coefficient, we examined with the help of a coefficient of determination what percentage of one variable explains the variance of the other variable. We also examined the relationship between the ratio of job vacancies to the number of unemployed and the ratio of the unemployed with primary education.

In Békés county, a trend similar to the national one took place in the period 2013-2019, unemployment decreased until 2016 and the job vacancy rate increased slightly, then the curve turned inwards thus, with fewer job vacancies, slightly more people sought work. In the case of Szabolcs-Szatmár-Bereg county, the curve also shifts inwards, here the shift is significant after 2014, with almost no change in the proportion of vacancies since 2015 , while unemployment decreased by $2.53 \%$ points.

In Borsod-Abaúj-Zemplén county, a completely different picture emerges, the decreasing unemployment rate from year to year was accompanied by an increasing job vacancy rate. The special situation was contributed by the fact that the demand for labor was the highest here in the years under review $(12.45 \%$ of all vacancies reported in 2019) and the highest number of unemployed with general or lower education was registered here (18,004 persons, $16.63 \%$ of job seekers). The outstanding demand for labor on the national average mainly meant low-skilled jobs for which support could be requested.

The research confirmed a positive medium relationship in the selected counties between the unemployment rate and the public employment rate.

The correlation between the job vacancy rate and the share of the unemployed with a primary education also showed a positive, strong relationship in all three counties. The coefficient showed a directly proportional relationship, the higher the proportion of peoples with primary education, the higher the demand for labor relative to the number of unemployed.

\section{REFERENCES}

Ministery of the Interior of Hungary (2019). Közfoglalkoztatás föbb adatai. Retrieved from http://kozfoglalkoztatas.bm.hu/

Bódi, F., Obádovics, C. (2000). Munkanélküliség a vidéki Magyarországon. Területi Statisztika, 40 (1), 55-69.

Brown, A. J. G., Koettl, J.(2012). Active Labor Market Programs: How, Why, When, and To What Extent are they Effective?. Europe and Central Asia Knowledge Brief, 58. World 
Bank, Washington, DC. Retrieved from https:/openknowledge.worldbank.org/ bitstream/handle/10986/17053/762120BRI0Box30OWLEDGE0NOTES0SERIES.pdf?s equence $=1$ \&isAllowed $=y$

Csoba, J. (2010). „Segély helyett munka.”A közfoglalkoztatás formái és sajátosságai. Szociológiai szemle, 20 (1), 26-50.

Egri, Z., Kőszegi, I.R. (2018). A gazdasági-társadalmi (komplex) térszerkezet kelet-középeurópai képe. Területi Statisztika, 58 (1), 27-56.

Egri, Z. (2019). A területi gazdasági fejlettség egyenlőtlenségei Békés megyében 1988-2017. In Egri Z. - Rákóczi A. (eds.): Társadalmi-gazdasági folyamatok a periférián - Békés megyei tapasztalatok, 4-31. SZIE-AGK, Szarvas.

European Commission (2013). Tervezet - Közös foglalkoztatási jelentés. Retrieved from https://eur-lex.europa.eu/LexUriServ/LexUriServ.do?uri=COM:2013:0801:FIN:HU: PDF

European Commission (2019). Labour Market Policy - Public expenditure on labour market policy interventions. Retrieved from https://webgate.ec.europa.eu/empl/redisstat/ databrowser/view/LMP_EXPSUMM/default/bar?lang=en\&category=lmp_expend

Fejes, L., Hollóné Foror, É., Horváth, B., Nagy, E., Póka, O., Szalainé Homola, A., ...Szűcs, L. (2006). A foglalkoztatás és munkanélküliség területi különbségei az elmúlt 55 évben, Központi Statisztikai Hivatal Miskolci Igazgatóság, Miskolc, 67.

Hajdú, D., Koncz, G._(2020). Álláskeresők támogatott felnőttképzésében résztvevők vizsgálata Borsod-Abaúj-Zemplén megyei helyszíneken Studia Mundi - Economica, 7 (1), 2-11.

Hawkins, D. (1980). „Identification of outliers”. Chapman \& Hall, London. ISBN: 978-94-0153994-4

Hudomiet, P., Kézdi, G. (2008). Az aktív munkaerö-piaci programok nemzetközi tapasztalatai. Kormányzás, Közpénzügyek, Szabályozás 3 (1), 3-37. Retrieved from http://www.kormanyzas.hu/081/01_Hudomiet-Kezdi.pdf.

Kálmán, J. (2015). A közfoglalkoztatási programok háttere és nemzetközi tapasztalatai in Fazekas K., Varga J. (eds.): Munkaerőpiaci Tükör, 2014. MTA Közgazdaság- és Regionális Tudományi Kutatóközpont Közgazdaság-tudományi Intézet, Budapest, 4265.

Kessing, S. G., Strozzi, C. (2017). The regional distribution of public employment: theory andevidence. Regional Studies, 51 (7), 1100-1114.

Lipták, K. (2014). Változó munkaerőpiac? Munkaerő-piaci előrejelzés Észak-Magyarországon, Területi Statisztika, 54 (3), 220.

Lodemel, I., Trickey, H. (2000). 'An offer you can't refuse'. Workfare in international perspective. The Policy Press, Bristol. 384.

Morvay, E. (2012). Munkapiac keresési surlódásokkal. Közgazdasági Szemle, 59 (2), 139-163.

Nemes Nagy, J. eds. (2005). Regionális elemzési módszerek. ELTE Regionális Földrajzi Tanszék, Budapest. Regionális Tudományi Tanulmányok, 11.

National Employment Service (2019). A nyilvántartott álláskeresők, a passzív ellátásban részesülők és a bejelentett álláshelyek fontosabb jellemzőinek adattára 2000. - 2020. havonta. Retrieved from https://nfsz.munka.hu/Lapok/full_afsz_kozos_statisztika /stat_afsz_nyilvtartasok.aspx

National Spatial Development and Spatial Planning Information System (2019). Interaktív elemző - Belügyminisztérium - Közfoglalkoztatási adatok. Retrieved from https://www.teir.hu/

Rodenburg, P. (2007). The remarkable palce of UV-curve in economic theory, Tinbergen Institute Discussion Paper, University of Amsterdam, Amsterdam, 34. 
Toh, R., Sampson, J. P. (2019): Improving public employment service delivery in developing countries: right servicing throughthe cognitive information processing approach. British Journal of Guidance \& Counselling, 47 (3).

Vargha, A. (2000). Matematikai statisztika pszichológiai, nyelvészeti és biológiai alkalmazásokkal. Budapest, Pólya Kiadó.

Verma, S. P. (1997): Sixteen statistical tests for outlier detection and rejection in evaluation of international geochemical reference materials: Example of Microgabbro PM-S. Geostandards Newsletter. 21, 59-75.

Vita, L. (2011). A statisztikai próbák gondolatvilága. Statisztikai Szemle, 89 (10-11), 11301149.

Wilcox, R. R. (1998). How many discoveries have been lost by ignoring modern statistical methods? American Psychologist, 53 (3), 300-314.

Zhang, D. (2017). A Coefficient of Determination for Generalized Linear Models. The American Statistician, 71 (4), 310-316.

Zimmermann, L. V. (2014). Why Guarantee Employment? Three Essays on the World's Largest Public Works Program. 214. In PhD dissertation, Doctor of Philosophy (Economics), The University of Michigan. 